\title{
INDIVIDUAL PROTECTION OF AIRCRAFT AS AN ESSENTIAL FACTOR OF FLYING IN CONFLICT ZONES AND TERRORIST THREAT AREAS
}

\author{
INDYWIDUALNA OCHRONA STATKÓW \\ POWIETRZNYCH NIEZBĘDNYM WARUNKIEM \\ LOTÓW W STREFACH KONFLIKTÓW I ZAGROŻEŃ \\ TERRORYSTYCZNYCH
}

\author{
Andrzej Lewandowski ${ }^{1}$, Leszek Loroch ${ }^{2}$, Monika Świech ${ }^{3}$ \\ (1) (2) (3) Air Force Institute of Technology \\ Instytut Techniczny Wojsk Lotniczych \\ 01-494 Warszawa ul. Księcia Bolesława 6
}

e-mails: (2) leszek.loroch@itwl.pl, (3) monika.swiech@itwl.pl

\begin{abstract}
The paper presents ground-to-air weapon threats for aircraft, especially regarding man-portable air-defense systems (MANPADS) and the methods for reducing the threats. Polish participation in military conflicts along with international terrorism result in increasing threats for aircraft. The conducted analysis result in efforts for providing individual protection of aircraft and new countermeasures. Employment of these systems on military aircraft contributes to improved flight safety in threat areas, however expensiveness of individual protection systems make them uncommon on civil aircraft.
\end{abstract}

Keywords: terrorism threats, aviation safety, MANPADS

Streszczenie: Praca przedstawia zagrożenia dla statków powietrznych (SP) ze strony naziemnych środków ogniowych, szczególnie przenośnych przeciwlotniczych zestawów rakietowych oraz sposoby zmniejszenia zagrożenia. Polski udział w konfliktach zbrojnych i terroryzm międzynarodowy przyczyniają się do zwiększenia zagrożeń. Wskutek analiz, podejmowane są prace w zakresie indywidualnej ochrony SP i nowych sposobów przeciwdziałania. Wyposażenie wojskowych SP w te systemy poprawia bezpieczeństwo lotów w strefach zagrożeń, lecz wysoki koszt systemów powoduje, że cywilne SP nie są w nie wyposażane.

Słowa kluczowe: zagrożenia terrorystyczne, bezpieczeństwo lotów, MANPADS. 


\section{INDIVIDUAL PROTECTION OF AIRCRAFT AS AN ESSENTIAL FACTOR OF FLYING IN CONFLICT ZONES AND TERRORIST THREAT AREAS}

\section{Introduction}

The paper presents terrorist ground-to-air weapon threats for military and civil aircraft, especially regarding man-portable air-defense systems (MANPADS) and the methods for reducing the threats. Nowadays about 20 countries produces 37 kinds of man-portable air defence systems (MANPADS). It is estimated that since the invention of MANPADS in the turn of the '50s and 60's around 1 million pieces have been manufactured. The MANPADS threat for all kinds of aircraft rises constantly due to the fact that the non-proliferation regulation process runs very slowly. The 1995 Wassenaar Agreement on Export Controls for Conventional Arms and Dual-Use Technologies was only implemented by 33 countries. It is supposed that 350-700 thousand MANPADS belong to arsenals of over 100 countries.

Non-state actors, such as terrorist groups can have admission to over 100 thousand MANPADS. After the September 11th attack on WTC, restricted control procedures were implemented into airports. Due to the improved security on airports the terrorist threat moved beyond the protected area, where weapons like MANPADS can be employed.

This is a subject of special importance for states involved in military operations in Iraq and Afghanistan, as well as for the whole European Union whose contingent is planned to be send to Chad, where a serious arsenal of different kinds of weapons is beyond the governmental control. For this reason the employment of individual protection assets on commercial and military aircraft becomes the issue of great importance. This can contribute to the improved flight safety in threat areas.

\section{The ground-to-air fire assets threats for civilian and military aircraft}

The analyses of the recent local wars indicate a serious employment of antiaircraft assets, which can cause serious threat for the enemy's air forces. During the Vietnam war, different kinds of fire assets, from AK-47 to antiair guns and artillery, including the first-used MANPADS (see Figure 1), were employed. 80 percent of the aircraft damage incidents were caused by ground-to-air fire assets. The threat for aircraft has continuously been rising ever since. 


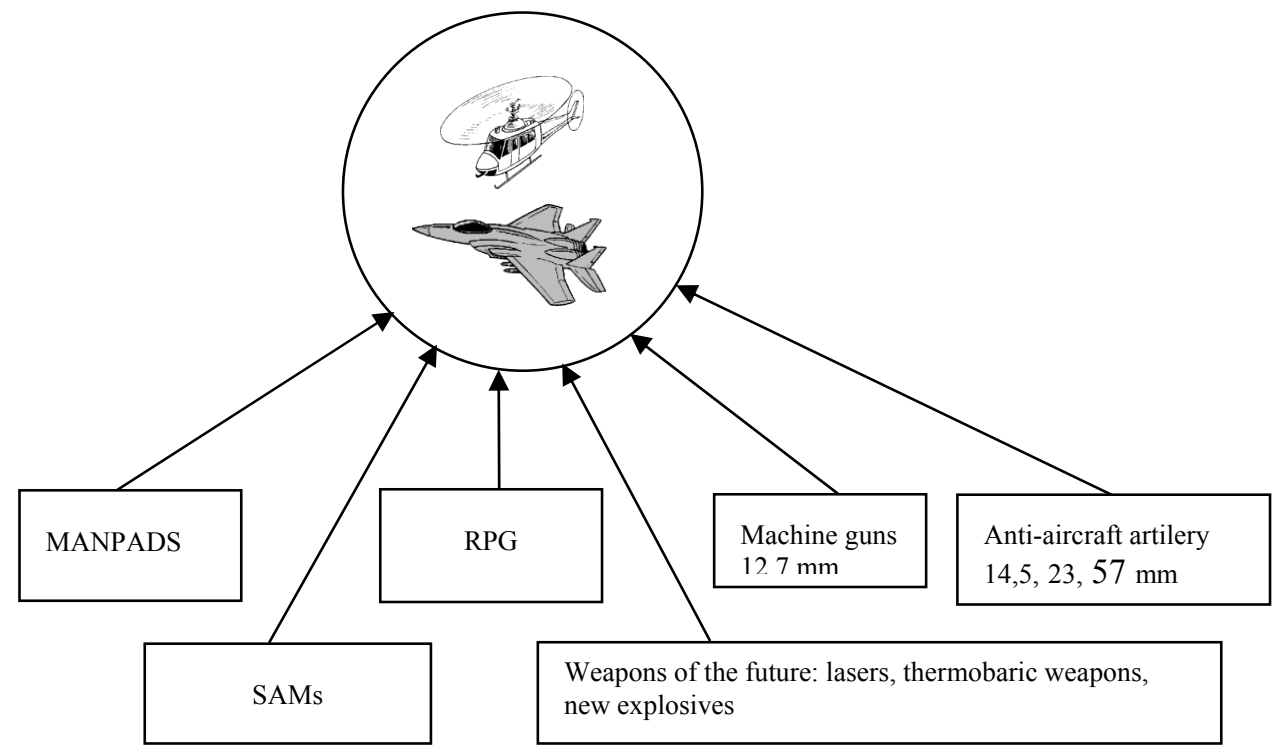

Fig. 1 Ground-to-air fire assets

The mass-scaled employment of MANPADS was the case during the 1979 Afghanistan war, when mujahedins shot down 300 soviet aircraft with about 1000 American MANPADS.

The Balkan war provided another example, were NATO forces lost 61 combat aircraft, 7 helicopters, 30 unmanned aerial vehicles (UAVs) and 238 self-guided missiles.

The Iraq case presents a similar level of this kind of threats for air traffic. It is estimated that despite detecting and neutralizing of about 6 thousand MANPADS in 2002, 4-5 thousand MANPADS are still in hands of the antigovernmental forces. For the last five years 36 incidents of attacks against transport aircraft have taken place. Several single cases of battering helicopters have happened. The situation is similar in Afghanistan, where attacks are directed mainly against transport aircraft.

The spectrum of ground fire assets against aircraft becomes wider. Beside MANPADS there are employed large-calibre machine guns and grenade launchers for destroying aircraft on ground. In the future, the greatest threat among MANPADS will be made by radio-guided (Javelin, Starburst) and laser-guided (RBS-70, Starstreak) systems.

A lot of them are implemented into countries described by the United Nations as unstable. For instance, one of the most lethal artillery-missile systems, Pantsir-ISE, was delivered to the United Arab Emirates (50 pieces), and another deliveries are planned to Algeria and Syria. 
Table 1. Suspected Shoulder-Fired Missile Attacks Against Large Civilian Turbojet Aircraft (1978-Present)

\begin{tabular}{|c|c|c|c|c|}
\hline Date & Location & Aircraft & Operator & Outcome \\
\hline $\begin{array}{l}12- \\
\text { Feb- } \\
1979\end{array}$ & Zimbabwe & Viscount & $\begin{array}{l}\text { Air } \\
\text { Rhodesia }\end{array}$ & $\begin{array}{l}\text { Catastrophic: } 59 \text { fatalities } \\
\text { of } 130 \text { people on board. }\end{array}$ \\
\hline $\begin{array}{l}8- \\
\text { Nov- } \\
1983\end{array}$ & Angola & Boeing 737 & $\begin{array}{l}\text { Angolan } \\
\text { Airlines } \\
\text { (TAAG) }\end{array}$ & $\begin{array}{l}\text { Catastrophic: } 130 \text { fatalities } \\
\text { of } 130 \text { people on board. }\end{array}$ \\
\hline $\begin{array}{l}\text { 9-Feb- } \\
1984\end{array}$ & Angola & Boeing 737 & $\begin{array}{l}\text { Angolan } \\
\text { Airlines } \\
\text { (TAAG) }\end{array}$ & $\begin{array}{l}\text { Hull Loss: aircraft overran } \\
\text { runway on landing after } \\
\text { being struck by a missile at } \\
8,000 \mathrm{ft} \text { during climb out. } \\
\text { No fatalities with } 130 \text { on } \\
\text { board. }\end{array}$ \\
\hline $\begin{array}{l}21- \\
\text { Sep- } \\
1984\end{array}$ & $\begin{array}{l}\text { Afghanista } \\
\mathrm{n}\end{array}$ & DC-10 & $\begin{array}{l}\text { Ariana } \\
\text { Afghan } \\
\text { Airlines }\end{array}$ & $\begin{array}{l}\text { Substantial Damage: } \\
\text { Aircraft was damaged by } \\
\text { the missile, including } \\
\text { damage of two hydraulic } \\
\text { systems, but landed without } \\
\text { further damage. No } \\
\text { fatalities. }\end{array}$ \\
\hline $\begin{array}{l}22- \\
\text { Sep- } \\
1993\end{array}$ & Angola & Tu-154 & $\begin{array}{l}\text { Transair } \\
\text { Georgian } \\
\text { Airlines }\end{array}$ & $\begin{array}{l}\text { Catastrophic: Shot on take- } \\
\text { off by unknown weapon. } \\
106 \text { fatalities. }\end{array}$ \\
\hline $\begin{array}{l}10- \\
\text { Oct- } \\
1998\end{array}$ & $\begin{array}{l}\text { Democratic } \\
\text { Republic of } \\
\text { Congo }\end{array}$ & Boeing 727 & $\begin{array}{l}\text { Congo } \\
\text { Airlines }\end{array}$ & $\begin{array}{l}\text { Catastrophic: } 41 \text { fatalities } \\
\text { of } 41 \text { people on board. }\end{array}$ \\
\hline $\begin{array}{l}\text { Nov- } \\
1999\end{array}$ & Angola & DC-3 & - & Shot down \\
\hline $\begin{array}{l}\text { Dec- } \\
1999\end{array}$ & Angola & C-130 & - & 14 fatalities \\
\hline $\begin{array}{l}28- \\
\text { Nov- } \\
2002\end{array}$ & Kenya & Boeing 757 & $\begin{array}{l}\text { Arkia } \\
\text { Israeli } \\
\text { Airlines }\end{array}$ & $\begin{array}{l}\text { Miss: Two SA-7's were } \\
\text { fired at the aircraft during } \\
\text { climb out, but missed. No } \\
\text { fatalities. }\end{array}$ \\
\hline $\begin{array}{l}22- \\
\text { Nov- } \\
2004\end{array}$ & Iraq & $\begin{array}{l}\text { Airbus } \\
\text { A300 }\end{array}$ & DHL Cargo & $\begin{array}{l}\text { Hull Loss: Aircraft wing } \\
\text { struck by missile departing } \\
\text { Baghdad. Aircraft suffered } \\
\text { a complete loss of } \\
\text { hydraulic power and } \\
\text { departed the runway during } \\
\text { an emergency landing. }\end{array}$ \\
\hline
\end{tabular}


Syria, which possesses SA-14 and SA-14, is going to purchase SA-18Needle from Belarus, as well. Iran has received a serious number of TORM1 systems, and further deliveries of S-300 systems are planned.

The above listed on-ground fire assets make significant threat for civilian aircraft, as well. For the last 28 years, 35 civilian aircraft have been attacked from ground, 24 of which were shot down. As a result, there have been at least 500 fatalities (see Table 1).

The experience has proved that the most sensitive time of attack is while taking off and landing, thus the most significant threat zone is nearby airports and airfields. Its spatial characteristics are illustrated at Figure 2.

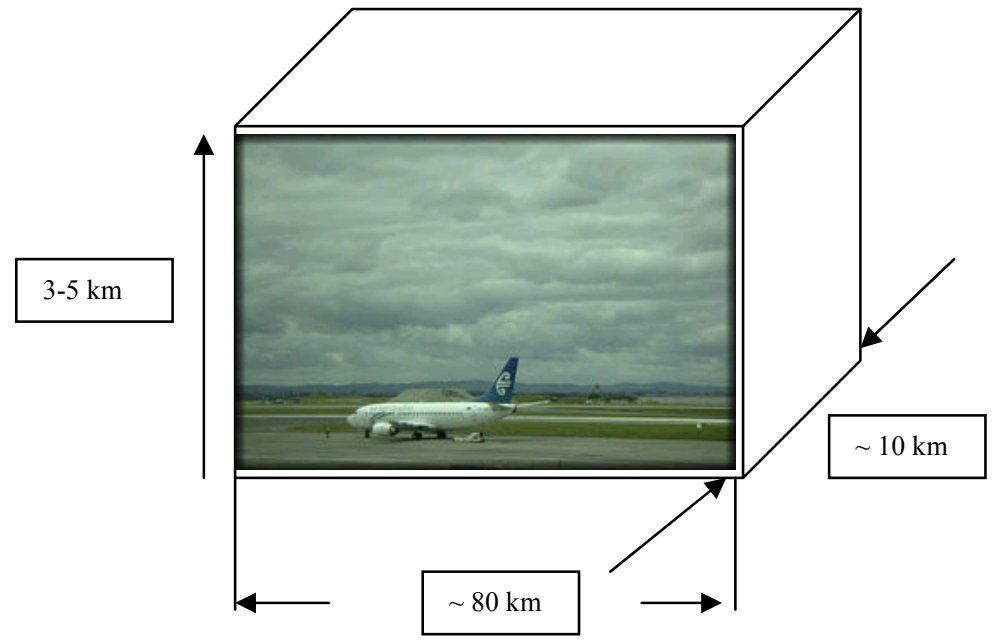

Figure 2. Airport's threat zone

\section{Technical and organizational actions for improving individual protection of aircraft in conflict and terrorist threat zones}

\subsection{Electronic Warfare (EW)}

The increasing threat by ground assets enforces the employment of aircraft individual protection assets (Figure 3). These assets make the elements of Electronic Warfare (EW). 


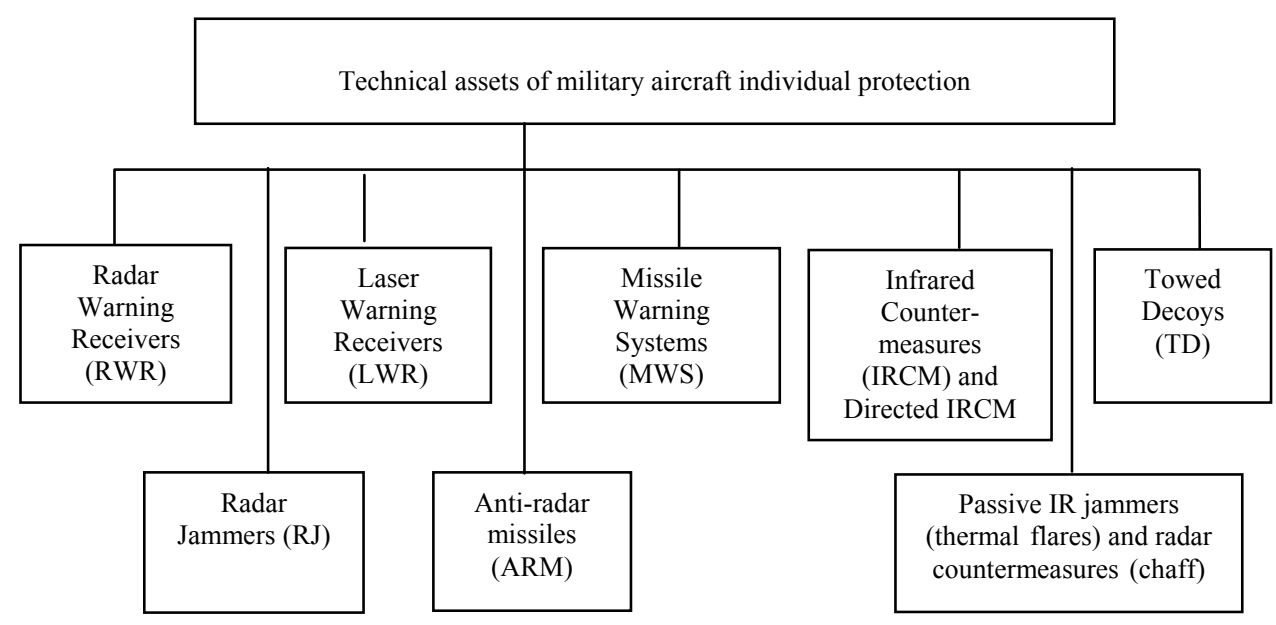

Figure 3 Technical assets of military aircraft individual protection

The EW has the following objectives:

- electronic air reconnaissance,

- Electronic Protective Measures (EPM),

- electronic self-protection and Electronic Countermeasures - ECM).

These tasks are performed by standard devices on aircraft. Some of them is also employed on civilian aircraft. All the on-board aircraft devices should be integrated, in order to provide appropriate navigation and in consequence high operational effectiveness. They should also cooperate with the IFF system (Identification "Friend-or-Foe") and Fire Control Radar.

\subsection{On-board EW systems}

On-board EW systems perform the functions of aircraft electronic selfprotection and enable safe accomplishment of combat missions. Figure 1 presents the following kinds of devices:

- warning/reconnaissance receivers: Radar Warning Receiver (RWR), Laser Warning Receiver (LWR) and Missile Warning System;

- radar jamming devices;

- IR noise and deceptive jammers: the allround-coverage Infrared Countermeasures (IRCM) and Directed Infrared Countermeasures (Directed IRCM);

- active IR jammers: Towed Decoy;

- passive IR jammers (thermal flares) and radar countermeasures (chaff);

- self-guided anti-radar missiles (ARMs). 
Indywidualna ochrona statków powietrznych.....

\subsection{Radiation warning receivers}

Radiation warning receivers make the most important component of aircraft EW self-protection.

\subsubsection{Radar Warning Receivers (RWR)}

Radar Warning Receivers can perform the tasks of frequency filtration, as well as threat identification and classification. The accuracy of angular measurement should average $1^{\circ}$, however it can even fall down to $10^{\circ}$. The data library should be composed of at least 1500 kinds of emitters (radiation sources).

\subsubsection{Laser Warning Receivers (LWR)}

Laser Warning Receivers (LWRs) are used for detecting, processing and imaging of threats, such as the enemy's laser system, range-finder or laser target illuminator.

The LWR's range of operation must ensure the sufficiently fast reaction against threat, that is optimal time of making the decision on the employment of self-protection measures. The LWR devices should have the capability of detecting the laser illuminators of semi-active guided missiles, laser guided surface-to-air missiles (SAM), laser guided anti-tank missiles that can provide threat for helicopters and commercial aircraft, hard \& soft kill laser weapons, and laser combinations of battlefield IFF.

\subsubsection{Missile Warning Systems (MWSs)}

Missile Warning Systems (MWSs) are used for detecting and identifying the threat (ballistic missile) type. The MWS is complementary to the RWR system whose detecting capabilities are limited to electromagnetic radiation. The LWR system is therefore destined to passive detection of IR / UV band signals. It has the advantage of faster detection of a missile, which gives more time for reaction between the moment of threat detection and hitting the target by the missile. The system informs on existence of the threat at the moment of firing the missile, which allows the self-system for the effective employment of Direct IRCM devices.

\subsubsection{Radar self-protection systems}

The EW experts classify self-protection measures as follows:

- On-Board Radar Countermeasures (On-Board RCM),

- On-Board Infrared Countermeasure subsystems (On-Board IRCM),

- Out-Board Radar Countermeasure (Out-Board CM),

- Out-Board Infrared Countermeasures (Out-Board IRCM),

- Laser Countermeasures Subsystems (LCMS). 


\subsubsection{Radar jammers}

Active jamming by On-board BRCM devices (radar jammers) consists in emitting jamming signals on the frequency of the operating radar station. These can be local jamming consisting in selective jamming of one of the detected radar stations that enables the application of high-power jamming; barrier jamming (emitted in wide band of frequency) that jams the operation of many assets at the same time, and "pulse jamming" (imitating the presence of at least several targets in the further distance), which jams the operation of pulse radars.

The most effective active jamming is performed by deceptive jammers, which operate using the signal retranslation technique.

The following group of devices perform the function of Out-Board Radar Countermeasure (OBCM): Towed Decoys, Forward Fired Expendable Decoys, Expendable Active Decoys and chaffs.

Forward Fired Expendable Decoys are usually artillery cartridges fired from an on-board gun and containing chaff loads. The task of these chaffs is to create a cloud, which makes a target for a radar, as it has large enough RCS reflecting surface (e.g. approximately $150 \mathrm{~m}^{2}$ ).

Expendable Active Decoys are stand-off ballistic missiles (decoys), equipped with emission systems and fired towards the enemy's air defence. Fired from the carrier's board they generate a signal, which imitates an echo signal of the object having the set RCS.

Chaffs make the last type within this class of jammers fired from on-board launchers in a similar way to thermal flares. The foundation of this solution is made by the theory of dipole antenna with a shorted output port. It was determined that the highest wave reflection capabilities occur while using dipoles with wavelength of 0,46-0,48.

\subsection{Infrared Countermeasures (IRCM)}

On-board IRCM systems are composed of jamming devices (e.g. AN/ALQ 144), which emit modulated energy in the selected IR band. This modulated energy (light pulses) causes targeting errors and in consequence retargeting by the nose-cone of the IR-targeted missile. Directed IRCM can dazzle (dazzling technique) or cause damages through concentric radiation of high intensity light. Employment of a laser or a special flashgun would make the typical DIRCM solution.

Thermal flares still remain the easiest and the cheapest IR jamming method. However, their employment in the contemporary battlefield becomes less 
and less effective, which was the case for Soviet military aviation during the Afghanistan war.

The effectiveness of this solution depends on the cooperation between the flare firing system and the threat detecting systems. The basic problem is to choose the right moment for flare firing (very short combustion time), the number of flares and firing sequences. The next generation flares will be developed in the way that would provide: longer combustion time, high combustion temperature (e.g Magnesium Teflon "Viton" - MTV), multispectral protection, better kinematics, and acting as dipoles at the same time.

On-board IRCM consist of devices which emit IR-band jamming (pulse code modulated electromagnetic radiation). They are based on mechanical optical system (rotary optical system with centrally placed radiation source) or on electronically modulated radiation source (plasma lamp, e.g. xenon lamp). Such devices are usually mounted in pairs on fuselage of the airframe.

\subsection{Laser Countermeasures Subsystems}

The main function of the Laser Countermeasures Subsystem is to increase the number of range-finding errors (retargeting errors) by the nose-cone of the ballistic missile in order to provide the missile's explosion in the safe distance.

Detection and identification of laser-based threats is performed by LWS (Laser Warning System) device along with other warning sensors. At present, laser threat can be neutralized by using narrowband filters against the most common wavelengths.

The most effective countermeasures against this kind of threats are provided through the emission of pulse train in the direction of range-finder head, in order to imitate the presence of at least several targets in the further distance.

\section{Organizational actions towards increasing aircraft's safety}

According to many opinions operational actions can make an effective method of self-defence of aircraft (especially as the cost of equipping aircraft with modern self-defence devices reaches up to $1-3$ million USD. They include aircrew training, reconnaissance of the area over which the flight will be made, securing airports and military airfields. 
Aircrew training should include the procedures for reducing the emission of radiation, as well as practicing anti-missile and anti-fire manoeuvres. The other way to reduce threat might be reducing the time of aircraft's presence in threat zone, reducing the number of night flights and reducing aircraft's weight.

Reducing the time of aircraft's presence in threat zone may be difficult, as the threat zone for aircraft is corresponds to the area of $80 \times 10 \mathrm{~km}$ (see Figure 2), and it can be secured with the state of the art short-range air defence systems, such as THEL, HUMRAAM or LOARA.

Exercising manoeuvres is not a simple task, either, especially for commercial and transport aircraft. It seems to be easier to train aircrew in the scope of take-off and landing techniques.

It is important to determine strict air traffic procedures, in order to make it difficult for terrorist groups to obtain the information on the aircraft's position. An attack during take-off and landing would be particularly dangerous. In consequence, the most dangerous zone for aircraft is nearby the airport/airfield (see. Figure 2).

\section{Conclusions}

1. Due to their availability, threats from ground fire assets, especially from MANPADS, high-calibre weapons and grenade launcher, will increase.

2. The aircraft's self-protection assets do not provide a complete protection against ground fire assets, and the opportunities of employing these assets on all aircraft in short time is very limited. Therefore prioritizing seems to be necessary.

3. A lot of attention should be paid to development of target imitating, particularly of towed decoys (radar or IR), whose effectiveness is higher then in case of any other passive method engaging electronic countermeasures.

4. Organizational actions are of great importance, due to their high effectiveness in combating against high-calibre weapons and grenade launchers. Such actions should consist in adequate aircrew training and providing reliable information on the threats.

5. It is important to pay more attention to organizational actions towards increasing airports' and airfields' safety (the same applies to the surrounding areas), as well as towards optimizing air traffic control procedures. 


\section{Acronyms:}

DIRCM Directed Infrared Countermeasures

ECM Electronic Countermeasures

ESM Electronic Support Measures

EW Electronic Warfare

FLIR Forward Looking Infrared

IR Infrared

IRCM Infrared Countermeasures

LWR Laser Warning Receiver

LCMS Laser Countermeasures Sub-System

MWS Missile Warning System

RWR Radar Warning Receiver

\section{References:}

1. Biuletyn $n r$ 3. Dowództwo Sił Powietrznych DWLOP wew.26/2006.

2. Bolkcom C., Elias B.: Homeland Security: Protecting Airlines from Terrorist Missiles. 12.12.2003- report for Congress - order Code RL31741

3. CRS Report RS21141. Military Suppresion of Enemy Air Defenses (SEAD). Assesing Future Needs.

4. Kopp C.: Are Helicopters Vulnerable? "Australian Aviation", No 59, March 2005, and "Man Portable Missiles US Airlines", December 2003.

5. Kosny A.: Środki obrony samolotów transportowych i pasażerskich, "Przegląd Sił Powietrznych", No 9, 2005.

6. Laurenzo R.: Antimissile Systems for Airlines. "Aerospace America", March 2005.

7. Lidyard G.: Air Countermeasures. URL: www.dlo.mod.uk.

8. O'Sullivan T.: Extend Terrorist Threats to Civilian Airlines: A Summary Risk Analysis of Manpads, Other Ballistic Weapons, Risks, Future Threats, and Possible Countermeasures Policies. Create report April 14, 2005.

9. Position of the Air Line Pilots Association, Int'l on MANPADS Countermeasures, February 2006, 75 years of pilots in command. 


\section{INDYWIDUALNA OCHRONA STATKÓW POWIETRZNYCH NIEZBĘDNYM WARUNKIEM LOTÓW W STREFACH KONFLIKTÓW I ZAGROŻEŃ TERRORYSTYCZNYCH}

\section{Wstęp}

Praca przedstawia zagrożenia dla statków powietrznych (SP) ze strony naziemnych środków ogniowych, szczególnie przenośnych przeciwlotniczych zestawów rakietowych oraz sposoby zmniejszenia zagrożenia.

Obecnie około 20 państw produkuje 37 rodzajów MANPADS. Szacuje się, że od ich wynalezienia na przełomie lat 50 i 60 -tych wyprodukowano około $1 \mathrm{mln}$ sztuk. Zagrożenie ze strony MANPADS dla wszystkich typów statków powietrznych systematycznie rośnie, z uwagi na fakt, że proces uregulowania nieproliferacji tego rodzaju uzbrojenia przebiega bardzo powoli. Umowa „The Wassenaar Arrangement on Export Controls for Conven-tional Arms and Dual-Use Technologies" z 1995 r. została wprowadzona tylko przez 33 państwa. Przypuszcza się, że 350-700 tys. MANPADS znajduje się $\mathrm{w}$ arsenałach ponad 100 państw.

Aktorzy pozapaństwowi, tacy jak organizacje terrorystyczne moga dysponować dostępem do ponad 100 tys. MANPADS. Po ataku na WTC we wrześniu 2001, wprowadzono zaostrzone procedury kontrolne w portach lotniczych. Spowodowało to, że zagrożenie atakiem przeniosło się poza obszar chroniony, a jego źródłem stały się przenośne systemy przeciwlotnicze.

Zagadnienie to nabiera szczególnego znaczenia dla państw zaangażowanych w operacje wojskowe w Iraku i Afganistanie, oraz dla całej Unii Europejskiej, której kontyngent planowany jest do Czadu, gdzie poza kontrolą rządową znajduje się duży arsenał różnorakiej broni, w tym prawdopodobnie MANPADS. Z tego względu wyposażenie statków powietrznych (cywilne i wojskowe) w środki indywidualnej ochrony nabiera szczególnego znaczenia. Przedsięwzięcia te mogą się przyczynić do poprawy bezpieczeństwa lotów w strefach zagrożeń. 


\section{Zagrożenia dla wojskowych i cywilnych statków powietrznych ze strony naziemnych środków ogniowych}

Analizy najnowszych wojen lokalnych potwierdzają częste wykorzystanie środków obrony przeciwlotniczej, które mogą spowodować duże straty w siłach powietrznych strony przeciwnej. Podczas wojny wietnamskiej wykorzystano różnego rodzaju środki ogniowe, od AK-47 po karabiny i armaty przeciwlotnicze oraz po raz pierwszy przenośne przeciwlotnicze zestawy rakietowe (Rysunek 1). Te naziemne środki ogniowe były przyczyną zniszczenia $80 \%$ statków powietrznych. Od tego czasu, zagrożenia dla statków powietrznych systematycznie rosną.

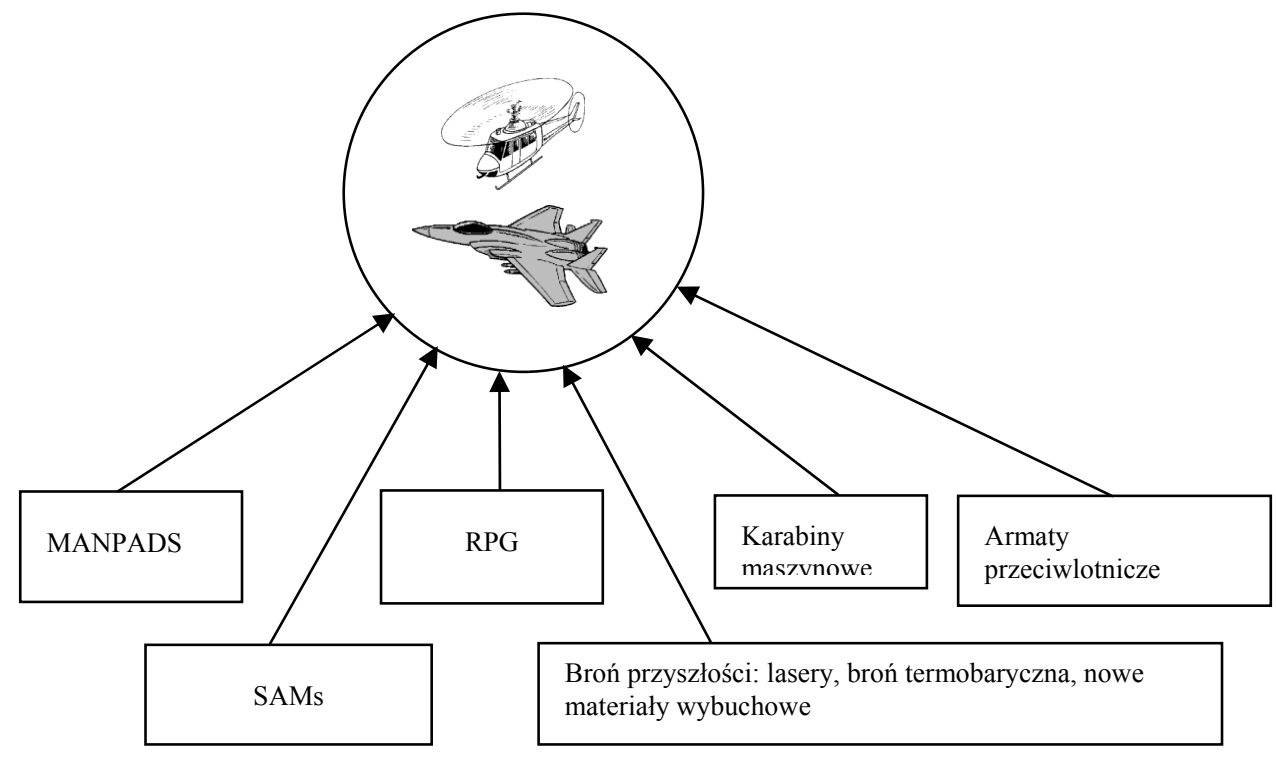

Rys. 1 Naziemne środki ogniowe

Po raz pierwszy na masową skalę użyto MANPADS-ów w wojnie w Afganistanie na przełomie lat 70 i 80 , gdzie mudżahedini przy pomocy otrzymanych od Amerykanów około 1000 przeciwlotniczych zestawów rakietowych zestrzelili 300 rosyjskich statków powietrznych.

Klasycznym tego przykładem może być operacja na Bałkanach, gdzie NATO straciło 61 samolotów bojowych, 7 śmigłowców, 30 samolotów bezzałogowych i 238 pocisków samosterujących.

Podobny poziom zagrożenia dla ruchu powietrznego występuje w Iraku. Szacuje się, że po wykryciu i neutralizacji, w grudniu 2002, składów $\mathrm{z}$ około 6 tysiącami MANPADS-ów, w rękach organizacji terrorystycznych znajduje się nadal 4-5 tysięcy tych zestawów. W ciągu ostatnich pięciu lat 
w Iraku odnotowano 36 ataków na samoloty transportowe. Pojedyncze przypadki ostrzelania śmigłowców miały miejsce kilkakrotnie. Podobnie wygląda sytuacja w Afganistanie i dotyczy głównie ataków na samoloty transportowe.

Tabela 1. Ataki na duże cywilne statki powietrzne dokonane prawdopodobnie z wykorzystaniem pocisków wystrzeliwanych z ramienia (1978-obecnie)

\begin{tabular}{|c|c|c|c|c|}
\hline Data & Miejsce & Samolot & Operator & Rezultat \\
\hline $\begin{array}{l}12 \text { lut. } \\
1979\end{array}$ & Zimbabwe & Viscount & $\begin{array}{l}\text { Air } \\
\text { Rhodesia }\end{array}$ & $\begin{array}{ll}\text { Katastrofalny: } 59 & \text { ofiar } \\
\text { śmiertelnych spośród } 130 \text { osób } \\
\text { na pokładzie. }\end{array}$ \\
\hline $\begin{array}{l}8 \text { list. } \\
1983\end{array}$ & Angola & Boeing 737 & $\begin{array}{l}\text { Angolan } \\
\text { Airlines } \\
\text { (TAAG) }\end{array}$ & $\begin{array}{lll}\text { Katastrofalny: } 130 & \text { ofiar } \\
\text { śmiertelnych spośród } 130 \text { osób } \\
\text { na pokładzie. }\end{array}$ \\
\hline $\begin{array}{l}9 \text { lut. } \\
1984\end{array}$ & Angola & Boeing 737 & $\begin{array}{l}\text { Angolan } \\
\text { Airlines } \\
\text { (TAAG) }\end{array}$ & $\begin{array}{l}\text { Uszkodzenie kadłuba: samolot } \\
\text { nie trafił w pas startowy przy } \\
\text { lądowaniu, po uderzeniu przez } \\
\text { pocisk na wysokości } 8,000 \text { stóp } \\
\text { podczas wznoszenia. Brak ofiar } \\
\text { śmiertelnych. }\end{array}$ \\
\hline $\begin{array}{l}21 \text { wrz. } \\
1984\end{array}$ & Afganistan & DC-10 & $\begin{array}{l}\text { Ariana } \\
\text { Afghan } \\
\text { Airlines }\end{array}$ & $\begin{array}{l}\text { Pokaźne zniszczenia: } \\
\text { został uszkodzony pociskiem } \\
\text { (w tym uszkodzenie dwóch } \\
\text { systemów hydraulicznych), lecz } \\
\text { wylądował bez dalszych } \\
\text { zniszczeń. Brak } \\
\text { śmiertelnych. }\end{array}$ \\
\hline $\begin{array}{l}22 \text { wrz. } \\
1993\end{array}$ & Angola & Tu-154 & $\begin{array}{l}\text { Transair } \\
\text { Georgian } \\
\text { Airlines }\end{array}$ & $\begin{array}{l}\text { Katastrofalny: } \quad \text { Zestrzelony } \\
\text { podczas startu z nieznanej } \\
\text { broni. } 106 \text { ofiar śmiertelnych. }\end{array}$ \\
\hline $\begin{array}{l}10 \\
\text { paźdz. } \\
1998\end{array}$ & $\begin{array}{l}\text { Demokratyczn } \\
\text { a Republika } \\
\text { Kongo }\end{array}$ & Boeing 727 & $\begin{array}{l}\text { Congo } \\
\text { Airlines }\end{array}$ & 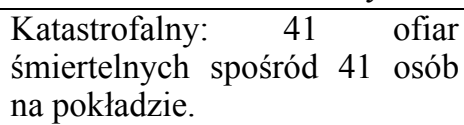 \\
\hline $\begin{array}{l}\text { List. } \\
1999\end{array}$ & Angola & DC-3 & - & Zestrzelony \\
\hline $\begin{array}{l}\text { Grud.1 } \\
999\end{array}$ & Angola & C-130 & - & 14 ofiar śmiertelnych \\
\hline $\begin{array}{l}28 \text { list. } \\
2002\end{array}$ & Kenia & Boeing 757 & $\begin{array}{l}\text { Arkia Israeli } \\
\text { Airlines }\end{array}$ & $\begin{array}{l}\text { Nietrafiony: Dwa SA-7 zostały } \\
\text { wystrzelone w samolot podczas } \\
\text { wznoszenia, jednak nie trafiły. } \\
\text { Brak ofiar. }\end{array}$ \\
\hline $\begin{array}{l}22 \text { list. } \\
2004\end{array}$ & Irak & Airbus A300 & DHL Cargo & 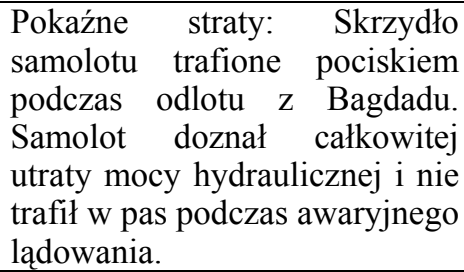 \\
\hline
\end{tabular}


Rozszerza się gama naziemnych środków ogniowych stanowiących zagrożenie dla statków powietrznych. Obok MANPADS-ów wykorzystuje się karabiny maszynowe dużego kalibru oraz granatniki. Większa gama środków może zostać użyta w działaniach prowadzonych na dużą skalę. Nie wolno zapominać, że spośród MANPADS szczególne zagrożenie będa stwarzać zestawy naprowadzane radiowo (typu Javelin, Starburst) i laserowo (RBS-70, Starstreak). Wiele $z$ nich jest implementowane do krajów ocenianych przez ONZ jako niestabilne. Przykładem może być dostawa jednego $\mathrm{z}$ najbardziej skutecznych zestawów artyleryjskorakietowych Pantsir-1SE do Zjednoczonych Emiratów Arabskich (50 szt.) oraz planowana dostawa tych zestawów do Algierii i Syrii. Syria zamierza również kupić SA-18-Igła od Białorusi, chociaż już posiada SA-14 i SA-16. Również Iran otrzymał znaczne ilości zestawów TOR-M1, a planowane sa do tego kraju dostawy zestawów S-300.

Przedstawione powyżej naziemne środki ogniowe stanowią również ogromne zagrożenie dla cywilnych statków powietrznych. W ostatnich 28 latach 35 samolotów cywilnych podlegało atakom z ziemi, z czego 24 zostały zestrzelone. W rezultacie tych ataków śmierć poniosło około 500 osób (Tabela 1).

Z doświadczenia wynika również, że najbardziej wrażliwym miejscem ataku jest atak w czasie startu lub lądowania, a stąd określa się, że najbardziej niebezpieczna strefa dla obiektów powietrznych znajduje się w pobliżu lotnisk. Jej wymiary przestrzenne pokazuje rysunek 2 .

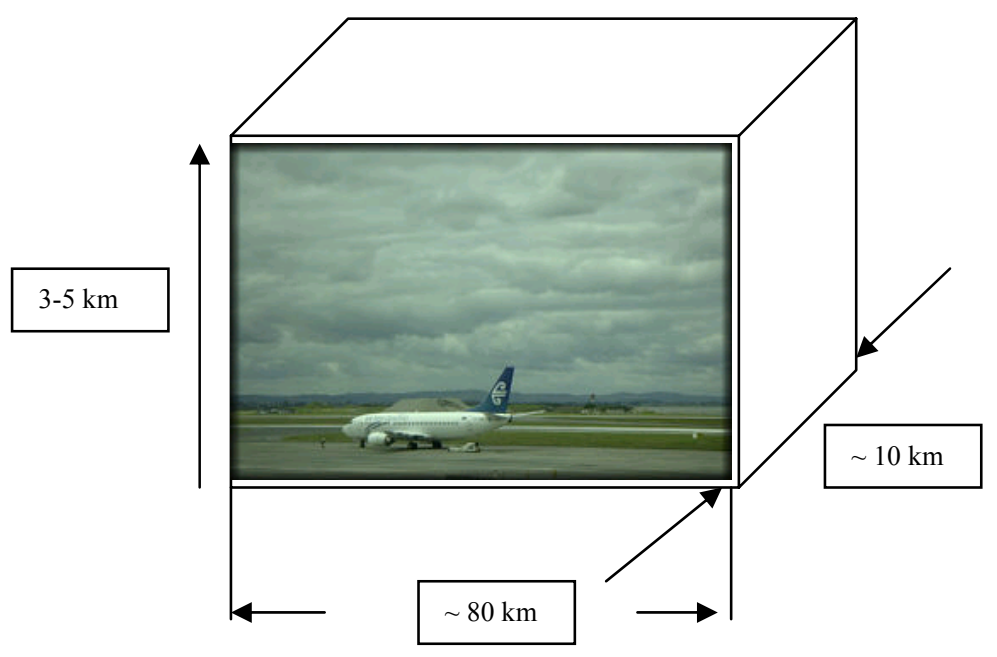

Rys. 2 Strefa zagrożenia dla lotniska 


\section{Techniczne i organizacyjne przedsięwzięcia poprawiające indywidualną ochronę statków powietrznych w strefach konfliktów i zagrożeń terrorystycznych}

\subsection{Walka radioelektroniczna}

Wzrost zagrożenia ze strony naziemnych środków ogniowych wymusza zastosowanie technicznych środków ochrony indywidualnej statków powietrznych (Rysunek 3). Urządzenia te stanowią elementy walki radioelektronicznej (EW - Electronic Warfare).

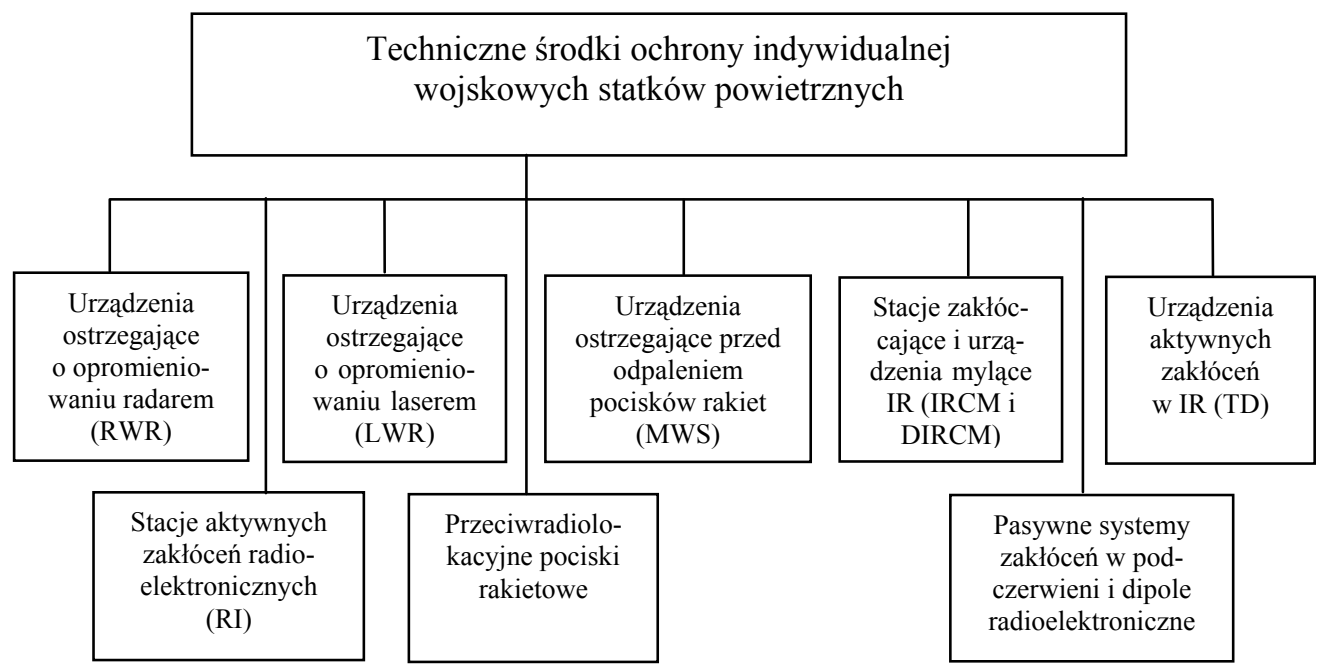

Rys. 3. Techniczne środki ochrony indywidualnej wojskowych statków powietrznych

W ramach walki radioelektronicznej realizowane są następujące zadania:

- prowadzi się powietrzne rozpoznanie radioelektroniczne

- prowadzi się przeciwdziałanie zakłóceniom radioelektronicznym - EPM (Electronic Protective Measures);

- zapewnia się osłonę radioelektroniczną (self protection) i przeciwdziałanie technicznym środkom rozpoznania nieprzyjaciela (ECM - Electronic Countermeasures).

Zadania te wypełniają urządzenia montowane standardowo na wojskowych statkach powietrznych. Część z nich jest również wykorzystywana przez cywilne statki powietrzne.

Całość urządzeń EW, znajdujących się na pokładzie statku powietrznego, powinna być zintegrowana $\mathrm{w}$ celu zapewnienia właściwego sterowania 
umożliwiającego osiagnnięcie wysokiej efektywności działania. Powinny one także współpracować z systemem IFF („Swój-Obcy”) oraz pokładowym celownikiem radiolokacyjnym (Fire Control Radar).

\subsection{Pokładowe systemy walki radioelektronicznej (EW)}

Pokładowe systemy walki radioelektronicznej są urządzeniami związanymi bezpośrednio z osłoną radioelektroniczną statków powietrznych, umożliwiające względnie bezpieczne wykonywanie zadań bojowych.

Wyróżnia się następujące rodzaje urządzeń: (schemat 1).

- odbiorniki ostrzegawczo-rozpoznawcze: urządzenia ostrzegające o opromieniowaniu radarem RWR (Radar Warning Receiver), urządzenia ostrzegające o opromieniowaniu laserem LWR (Laser Warning Receiver) oraz urządzenia ostrzegające przed odpaleniem pocisków rakietowych MWS (Missile Warning System);

- stacje aktywnych zakłóceń radioelektronicznych (Radar Jamming);

- stacje zakłócające i urządzenia mylące pracujące w podczerwieni: IRCM (Infrared Countermeasures)- pracujące dookolnie, DIRCM (Directed IRCM) - pracujące kierunkowo;

- urządzenia aktywnych zakłóceń w podczerwieni : Towed Decoy (holowane pułapki-wabiki);

- pasywne systemy zakłóceń w podczerwieni (flary termiczne) oraz w zakresach pracy systemów radiolokacyjnych: Chaff (dipole);

- samonaprowadzające się rakiety przeciwradiolokacyjne.

\subsection{Urzqdzenia ostrzegajqce o opromieniowaniu}

Urządzenia tego typu to najważniejszy element osłony radioelektronicznej samolotu.

\subsubsection{Urzqdzenia ostrzegające o opromieniowaniu radarem.}

Urządzenia ostrzegające o opromieniowaniu RWR może dokonywać filtracji częstotliwościowej, identyfikacji zagrożeń i uszeregowania zagrożeń. Dokładność namiaru kątowego powinna być rzędu $1^{\circ}$ (wartość średnia), jednak przy wykonywaniu złożonych manewrów przez samolot dopuszczalny jest spadek dokładności nawet do $10^{\circ}$. Zakładana pojemność biblioteki danych powinna wynosić co najmniej 1500 rodzajów nadajników (źródeł promieniowania). 


\subsection{Urzadzenia ostrzegające o opromieniowaniu laserem (LWR)}

Urządzenia ostrzegające o opromieniowaniu laserem LWR przeznaczone są do wykrycia, obróbki i zobrazowania zagrożeń związanych z oświetleniem statku powietrznego przez wrogi system laserowy, dalmierz bądź laserowy podświetlacz celu.

Zakres pracy urządzenia musi zapewnić wystarczająco szybką reakcję na zagrożenie, rozumianą jako szybkość podjęcia decyzji o użyciu środków obrony własnej. Stwierdzono, że urządzenia LWR powinny być zdolne do wykrywania podświetlaczy laserowych półaktywnie naprowadzanych pocisków rakietowych, laserowo naprowadzanych pocisków ziemiapowietrze (SAM), laserowo naprowadzanych pocisków przeciwczołgowych, które mogą stanowić zagrożenie dla śmigłowców i lotnictwa transportowego, broni laserowej różnej mocy (hard \& soft kill) oraz laserowych kombinacji systemów IFF (battelfield IFF).

\subsection{Urzqdzenia ostrzegające o wystrzeleniu pocisku rakietowego (MWS)}

Urządzenie ostrzegające o wystrzeleniu rakiety MWS ma za zadanie wykryć i określić rodzaj zagrożenia (typ pocisku rakietowego). System MWS pomyślany jest jako uzupełnienie systemu RWR, którego głównym ograniczeniem jest możliwość detekcji wyłącznie obecnego w przestrzeni promieniowania elektromagnetycznego. System MWS przeznaczony jest zatem do pasywnej detekcji sygnałów w przestrzeni w zakresie pasma podczerwieni i ultrafioletu. Zaletą systemu pasywnego wykrywania jest lepszy czas wykrycia (dłuższy okres pomiędzy detekcją zagrożenia a uderzeniem pocisku). System ten daje informację o wystapieniu zagrożenia już $\mathrm{w}$ chwili odpalenia pocisku, co $\mathrm{z}$ kolei daje możliwość systemowi osłony własnej skutecznie użyć urządzenie klasy DIRCM.

\subsection{Systemy oslony radioelektronicznej}

Wśród specjalistów EW stosuje się następujący podział środków przeciwdziałania:

- pokładowe środki zakłócające systemy radiolokacyjne On-Board BRCM (On-Board Radar Countermeasure);

- pokładowe podsystemy środków zakłócających urządzenia pracujące w podczerwieni On-Board IRCM (On-board Infrared Countermeasure subsystem); 
Indywidualna ochrona statków powietrznych.....

- pozapokładowe środki zakłócające systemy radiolokacyjne Out-board CM (Out-board Radar Countermeasure);

- pozapokładowe środki zakłóceń systemów pracujących w podczerwieni Out-board IRCM (Out-board Infrared Countermeasures);

- podsystemy przeciwdziałania urządzeniom laserowym LCMS (Laser Countermeasures sub-system).

\subsection{Urządzenia zaklócające pracę radarów.}

Zakłócenia aktywne OBRCM (urządzenia zakłócające radary - radar jammer) realizowane są poprzez wysyłanie sygnałów zakłócających na częstotliwościach pracującej SRL. Mogą być to zakłócenia miejscowe, polegające na zakłócaniu selektywnym jednej wykrytej SRL, możliwe jest wtedy zastosowanie dużej mocy zakłóceń, zakłócenia zaporowe (nadawane w szerokim paśmie częstotliwości), zakłócające pracę wielu różnych środków jednocześnie oraz zakłócenia kroczące (odprowadzanie w odległości), zakłócające pracę radarów impulsowych.

Najskuteczniejszym typem zakłóceń aktywnych są tzw. zakłócenia mylące, wykorzystujące technikę retranslacji sygnałów.

Pozapokładowe środki zakłóceń pracy radarów stanowi następująca grupa urządzeń: cele holowane (wabiki) (Towed Decoy), cele (wabiki) jednorazowego użytku wystrzeliwane w przednią półsferę (Forward Fired Expendable Decoy); Expendable Active Decoy oraz dipole radiolokacyjne (Chaff).

Cele (imitatory celów - wabiki) jednorazowego użytku wystrzeliwane w przednią półsferę (Forward Fired Expendable Decoy) to zazwyczaj naboje artyleryjskie wystrzeliwane $\mathrm{z}$ pokładowego działka, zawierające ładunki stanowiące dipole radiolokacyjne. Zadaniem tych dipoli jest stworzenie chmury, stanowiącej dla radiolokatora cel o odpowiednio dużej powierzchni odbicia RCS (np. rzędu $150 \mathrm{~m}^{2}$ ).

Expendable Active Decoy to pociski rakietowe (imitatory celów-wabiki) klasy stand-off zawierające układy nadawcze, wstrzeliwane w obronę plot. nieprzyjaciela. Wystrzelone z pokładu nosiciela generują sygnał imitujący sygnał echa od obiektu o zadanej RCS.

Ostatnim typem $\mathrm{w}$ tej klasie zakłóceń są dipole radiolokacyjne, wystrzeliwane z pokładowych wyrzutni na podobnej zasadzie jak flary termiczne. U podstaw tego rozwiązania leży teoria anteny dipolowej, której wyjściowy port jest zwarty. Stwierdzono, że największe możliwości 
refleksyjne fal występują przy zastosowaniu dipoli o długości $0,46 \div 0,48$ długości fali.

\subsection{Urządzenia zaktócające w podczerwieni (IRCM)}

Pokładowe systemy IRCM (Infrared Countermeasure) to urządzenia zakłócające (np. AN/ALQ 144), które emitują modulowaną energię w wybranym zakresie podczerwieni. Ta modulowana energia (impulsy świetlne) powoduje błędy i w rezultacie przecelowanie przez głowice pocisku naprowadzanego na podczerwień. Kierunkowe źródła zakłóceń DIRCM w podczerwieni, mogą oślepiać (technika dazzlingu) bądź uszkadzać poprzez koncentryczne promieniowanie światła o dużym natężeniu. Typowym rozwiązaniem DIRCM jest zastosowanie lasera bądź specjalnej lampy błyskowej.

Flary termiczne nadal pozostają najprostszym i najtańszym sposobem zakłócania w podczerwieni. Użycie ich na współczesnym polu walki staje się coraz bardziej nieefektywne, czego doświadczyło w szczególności lotnictwo byłego ZSRR w czasie wojny w Afganistanie.

Skuteczność stosowania osłony w postaci obłoku promieniowania cieplnego zależy od współpracy systemu odpalającego flary z systemami wykrywania zagrożeń. Podstawowym problemem jest wybór odpowiedniego momentu odpalenia flar (bardzo krótki czas spalania), liczby flar i sekwencji odpaleń. Flary nowej generacji będą rozwijane pod kątem zapewnienia długiego czasu spalania ładunku, wysokiej temperatury spalania (jak np. Magnesium Teflon „Viton” - MTV), zapewnienie osłony wielospektralnej, poprawienie kinematyki i jednoczes-ne działanie jako dipole radiolokacyjne.

On-board IRCM, stanowią urządzenia wytwarzające zakłócenia w paśmie podczerwieni (modulowane kodem impulsowym promieniowanie elektromagnetyczne). Sa to urządzenia zrealizowane na bazie mechanicznego układu optycznego (obrotowy układ optyczny z centralnie umiejscowionym źródłem promieniowania), bądź na bazie elektronicznie modulowanego źródła promieniowania (lampa plazmowa, np. lampa ksenonowa). Urządzenia te są montowane zazwyczaj parami na kadłubie płatowca.

\subsection{Urzq̨dzenia zaktócające lasery (LCMS)}

Podstawowym zadaniem podsystemu LCMS (Laser Countermeasures Subsystem) jest zwiększanie błędów pomiaru odległości (błędy przecelowania) przez głowice pocisku rakietowego, co ma spowodować rozerwanie pocisku w bezpiecznej odległości. 
Detekcja i identyfikacja zagrożeń związanych z wykorzystaniem techniki laserowej jest realizowana przez urządzenie LWS w połączeniu $\mathrm{z}$ innymi czujnikami ostrzegawczymi. Obecnie zagrożenie laserowe może być odparte przy wykorzystaniu wąskopasmowych filtrów skierowanych przeciw najbardziej rozpowszechnionym długościom fal.

Najskuteczniejszym sposobem zwalczania tego typu zagrożeń jest emisja serii impulsów o odpowiednim poziomie amplitudy w kierunku głowicy dalmierza, celem zaimitowania obecności co najmniej kilku celów na większych odległościach.

\section{Organizacyjne przedsięwzięcia zwiększające bezpieczeństwo statków powietrznych}

Według wielu poglądów skuteczną obroną statków powietrznych przed oddziaływaniem środków ogniowych obok przedsięwzięć technicznych stanowią przedsięwzięcia organizacyjne (tym bardziej, że wyposażenie statku powietrznego $\mathrm{w}$ nowo-czesne urządzenia indywidualnej ochrony to koszt $1-3$ mln \$). Obejmują one szkolenie obsług samolotów, rozpoznanie terenu, nad którym wykonywane są loty i bezpośrednią obronę portów lotniczych i lotnisk wojskowych.

Szkolenie załóg powinno dotyczyć przestrzegania procedur $\mathrm{w}$ zakresie ograniczenia emisji promieniowania oraz wykonywania manewrów przeciwrakietowych i przeciw-ogniowych. Innym sposobem zmniejszającym zagrożenie może być ograniczenie przebywania statku powietrznego w strefie zagrożenia, ograniczenie wykonywania lotów nocą i zmniejszenie wagi masy samolotu. To pierwsze wydaje się bardzo trudne do realizacji, gdyż strefa zagrożenia dla samolotu (rys.2) wynosi 80 na 10 $\mathrm{km}$. Odpowiednie zabezpieczenie tej strefy może być realizowane przez najnowocześniejsze systemy przeciwlotnicze bliskiego zasięgu, takie jak THEL, HUMRAAM czy LOARA.

Wykonywanie manewrów, jak np. lot spiralny jest również niełatwy do realizacji, szczególnie przez samoloty pasażerskie i transportowe. Łatwiejszym wydaje się przeszkolenie (często $\mathrm{z}$ wykorzystaniem trenażerów) obsług samolotów i śmigłowców w zakresie techniki lądowania i startu.

Przedsięwzięciem organizacyjnym jest ścisłe określenie procedur ruchu lotniczego, mające na celu utrudnienie grupom terrorystycznym dotarcia do informacji o pozycji statku powietrznego.

Z doświadczeń wynika, że najbardziej niebezpiecznym miejscem ataku jest atak w czasie startu lub lądowania, a stąd określa się, że najbardziej 
niebezpieczna strefa dla obiektów powietrznych znajduje się w pobliżu lotnisk. Jej wymiary przestrzenne pokazuje rysunek 2 .

\section{Wnioski}

1. Z uwagi na dostępność zagrożenie ze strony naziemnych środków ogniowych, w tym szczególnie MANPADS, broni wielkokalibrowej i RPG, będzie wzrastało.

2. Środki ochrony indywidualnej statków powietrznych nie zapewniają pełnej ochrony przed oddziaływaniem naziemnych środków ogniowych, nie ma również możliwości wyposażenia wszystkich statków powietrznych $\mathrm{w}$ te środki w krótkim czasie, stąd celowym wydaje się określenie priorytetów $w$ tym zakresie.

3. Dużą wagę należy zwrócić na rozwój środków pozoracji (imitacji celów), szczególnie holowanym wabikom (radiolokacyjnym jak i na podczerwień), których skuteczność jest wyższa od wszystkich znanych pasywnych metod przeciwdziałania radioelektronicznego.

4. Duże znaczenie mają przedsięwzięcia organizacyjne skuteczne w walce z bronią wielkokalibrową i RPG, polegające na dobrym wyszkoleniu załóg statków powietrznych oraz zapewnieniu załogom informacji o tych zagrożeniach.

5. Ważnym zagadnieniem jest zwiększenie zakresu przedsięwzięć organizacyjnych mających na celu wzrost bezpieczeństwa na lotniskach i wokół nich (airfield protection) oraz zmodyfikowanie procedur kontroli ruchu lotniczego.

\section{Wykaz skrótów i akronimów}

DIRCM (Directed Infrared Countermeasures) - stacje kierunkowego zakłócania w podczerwieni;

ECM (Electronic Countermeasures) - zakłócenia elektroniczne;

ESM (Electronic Support Measures) - wsparcie walki elektronicznej (wykrywanie i lokacja źródeł promieniowania);

EW (Electronic Warfare) - walka radioelektroniczna (WRE);

FLIR (Forward Looking Infrared) - kamera obserwacji przestrzeni w zakresie podczerwieni;

IR (Infrared) - podczerwień;

IRCM (Infrared Countermeasures) - stacje zakłócające i urządzenia mylące pracujące $\mathrm{w}$ podczerwieni;

LWR (Laser Warning Receiver) - urządzenia ostrzegające o opromieniowaniu laserem ; 
LCMS (Laser Countermeasures sub-system) - podsystem przeciwdziałania urządzeniom laserowym;

MWS (Missile Warning System) - urządzenia ostrzegające przed odpaleniem pocisków rakietowych;

RWR (Radar Warning Receiver) - urządzenia ostrzegające o opromieniowaniu radarem.

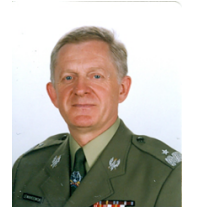

Major-General, Ph.D., Eng., LEWANDOWSKI Andrzej, Air Force Institute of Technology. Performed many responsible positions in Polish Air Defence Forces. 2003 - Ph.D. degree in military sciences. 2004-2007 attaché at Embassy of the Republic of Poland in Moscow.

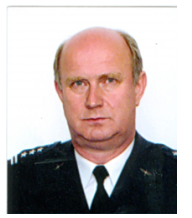

Ph.D., Eng., LOROCH Leszek, AFIT, R\&D coordinator of aeronautical projects. Specialist in the field of aircraft armament. Experienced in designing, testing, and implementation of modernized on-board aircraft armament and air combat assets. Former member of the commission for aircraft accidents investigation. A lot of publications in the field.

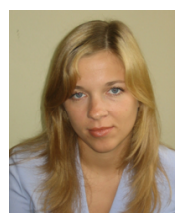

M.A., ŚWIECH Monika, Air Force Institute of Technology. Ph.D. programme at Jagiellonian University, Cracow, Poland, specialisation: Islamic terrorism, political violence, security research, international relations, European Union. Several publications in field. 
